Man and Nature

L'homme et la nature

\title{
Lillo and Moore in France: English Influences on the Dramatic Theory of Diderot
}

\section{F. M. Wilkshire}

Volume 5, 1986

URI : https://id.erudit.org/iderudit/1011863ar

DOI : https://doi.org/10.7202/1011863ar

Aller au sommaire du numéro

Éditeur(s)

Canadian Society for Eighteenth-Century Studies / Société canadienne d'étude du dix-huitième siècle

ISSN

0824-3298 (imprimé)

1927-8810 (numérique)

Découvrir la revue

Citer cet article

Wilkshire, F. M. (1986). Lillo and Moore in France: English Influences on the Dramatic Theory of Diderot. Man and Nature / L'homme et la nature, 5, 201-213. https://doi.org/10.7202/1011863ar

Copyright (C Canadian Society for Eighteenth-Century Studies / Sociéte canadienne d'étude du dix-huitième siècle, 1986
Ce document est protégé par la loi sur le droit d'auteur. L'utilisation des services d'Érudit (y compris la reproduction) est assujettie à sa politique d'utilisation que vous pouvez consulter en ligne.

https://apropos.erudit.org/fr/usagers/politique-dutilisation/ 


\section{Lillo and Moore in France: English Influences on the Dramatic Theory of Diderot.}

In the course of his writings on dramatic theory, Diderot makes frequent reference to two English tragedies, George Lillo's The London Merchant and Edward Moore's The Gamester. Neither of these plays enjoyed longterm success in England yet both exerted considerable influence on the Continent, particularly in France, where they were enthusiastically hailed as exemplifying a new 'genre,' the 'tragédie bourgeoise' as defined initially in the dramatic theories of Diderot. The aim of this paper is to trace the fate of these two plays in France and to examine the reasons for their strong appeal to Diderot.

The London Merchant or the History of George Barnwell was first performed at Drury Lane in 1731. Lillo, a Dissenter of Dutch origin, used an old English ballad as the basis for his play, a domestic tragedy with a heavy emphasis on the moral lesson. Barnwell, a naive young London apprentice, is seduced by Millwood, a prostitute, whose formidable influence leads him first to steal from his worthy employer, the merchant Thorowgood, and then to murder his uncle in order to receive his inheritance. Barnwell, in the throes of his fatal passion for Millwood, is unmoved by the entreaties of his long-suffering friend Trueman and of Maria, Thorowgood's daughter, by whom he is secretly loved. After the uncle's murder, Millwood, afraid that Barnwell's excessive remorse will cause him to reveal her involvement in the murder, denounces him. 
However, she, in turn, is denounced by her servants and both go to the gallows, Barnwell, repentant after much pathetic leave-taking, Millwood, defiantly unrepentant to the end. Names such as Thorowgood and Trueman together with the strong didactic element have led critics to describe The London Merchant as an eighteenth-century morality play and, in fact, it was frequently performed at holiday periods for the edification of London apprentices. The play contains a scene of seduction in Millwood's lodging, the murder of the uncle in a distant wood, pathetic scenes in Barnwell's prison cell and at the place of execution, and a view of the gallows. The latter was considered sufficiently audacious on the London stage to warrant some hesitation from Lillo as to whether or not it should be included.

The first mention of The London Merchant in France appeared in the Pour et Contre in 1734. ${ }^{1}$ The abbe Prévost wrote enthusiastically of the play, giving a synopsis of the plot and translating several scenes which he particularly admired. One of these was Act I, Scene III in which Millwood reveals her intention to seduce Barnwell. However, the actual seduction scene is omitted with the comment:

Cette Scène qui contient la séduction du jeune homme, est d'un tour tout-à-fait ingénieux et agréable; mais la bienséance française, plus rigoureuse que celle $\mathrm{d}^{\prime}$ Angleterre, ne me permet pas de la traduire. ${ }^{2}$

Although pronouncing the play a 'chef d'œuvre,' Prévost expresses his amazement at the playwright's total disregard for the usual conventions of tragedy:

Au reste, il n'y a pas un seul trait dans cette exposition qui ne se passe aux yeux des Spectateurs ... Tout s'exécute sur le Théâtre, sans aucun égard pour l'unité de tems et de lieu. ${ }^{3}$

A complete translation, Le marchand de Londres by Pierre Clément de Genève appeared in 1748. The translator uses, word for word, the scenes from the Pour et Contre but professes himself to be scandalized by what he considers the cruder elements of the play. He refuses to render the gallows scene, exclaiming pompously:

La plume me tombe de la main. Les scènes suivantes représentent le lieu de l'exécution; on y voit la Potence, le Boureau [sic], la Populace etc... ${ }^{4}$

nor is he above a sarcastic jibe at the English theatre. Of Act V, Scene IX, 
in which Maria is demented with grief at the impending fate of her lover, he remarks:

En bonne Police dramatique, Marie devroit se tuer ici; mais sur le théâtre Anglois ce n'est pas la peine de se tuer soimême; ce seroit un spectacle trop commun. Il faut quelque bon assassinat à coups redoublés, quelque bon parricide avec tous ses agréments. ${ }^{5}$

The translation is peppered with self-righteous asides and is modified in accordance with Clément's conception of what was decently acceptable to a French audience. This he freely admits in comments such as: 'J'ai fait ici quelques légers changements pour adoucir ce qu'il y avait de plus choquant.'6

Despite these changes, the play in its original form was still considered too crude to be performed on the French stage. However, several suitably toned-down versions were presented. Anseaume wrote a musical comedy entitled L'Ecole de la Jeunesse ou le Barnevelt français which was performed at the Théâtre-Italien in 1764. Not surprisingly, this bore little ressemblance to the original tragedy. Claude Dorat attempted a dramatic adaptation of the play but, as Lawrence Price indicates, ${ }^{7}$ was dismayed at the difficulty of the task of adapting a work in which 'rien n'est préparé, motivé, justifié.'

$\mathrm{He}$, in turn, found the play too brutal to be staged in France:

Souffriroit-on sur notre scène un enchaînement de crimes aussi révoltans, une suite de tableaux où l'intérêt doit toujours naître de la terreur? ${ }^{8}$

He finally abandoned the task and instead, in 1763, published a poem in the form of a letter from the imprisoned Barnwell to his friend Trueman. Diderot roundly attacked Dorat's work in a letter to Grimm describing it as 'un morceau faible, sans chaleur, sans poésie, sans mouvement.'

Louis-Sébastien Mercier made his own adaptation of Lillo's tragedy in 1769, calling it Jenneval ou le Barnevelt français. In the preface, he argues that the violence of the original tragedy is both unacceptable and unnecessary to the moral purpose of the play. In Mercier's version, Jenneval has a change of heart in time for the horror of parricide to be averted. The happy ending, in which virtue triumphs over evil, transforms the Mercier adaptation from tragedy to 'drame' without, according to the author, detracting from the moral impact of the play or offending what he refers to as 'la délicatesse française.' As he states in the preface: 
J'ai donc été obligé d'abandonner la pièce anglaise et de faire pour ainsi dire, un Drama nouveau ... Enfin, travaillant pour ma nation, je n'ai pas dû lui présenter des moeurs atroces. ${ }^{10}$

The last major French imitation was that of La Harpe. His version was published in 1778 under the title Barnevel, Drame imité de l'anglais en cinq actes et en vers and was intended to be read rather than staged. Despite this, the author recoils when confronted with the horror of the murder scene and comments that, in his version: '... l'action se passe entre les arbres qui dérobent au spectateur l'horreur du coup. ${ }^{\prime 11}$ Even the French reader must be protected from the barbarism of on-stage murder!

Edward Moore's The Gamester was written more than twenty years after Lillo's play and was staged at Drury Lane in 1753. It is a domestic tragedy in the style of The London Merchant concerning the fatal passion of gaming and its effects on Beverley, the main character, and his innocent family. The love of his long-suffering wife, the entreaties of his sister Charlotte and the faithful family friend Lewson, are all powerless to save him from his own obsession for gambling and from the treachery of the false friend Stukely, who, having persuaded Beverly to sell his wife's jewels, brings an action for debt against him and has him thrown into gaol. Beverley, filled with remorse and despair, drinks poison in his prison cell and expires surrounded by his distraught family; this, ironically, after Jarvis, the faithful old retainer, has brought news that Beverley's uncle has died leaving him a sizeable inheritance.

The play was less successful in London than Lillo's tragedy but had a considerable impact in France and Germany. Diderot's Le Joueur ${ }^{12}$ was the first French version of the play and, according to a letter to Sophie Volland in early September 1760, appears to have been translated at the request of his circle of friends at la Chevrette. Later that month, Diderot indicates the completion of his task:

Le Joueur est entre les mains de M. d'Argental qui en a désiré le lecture; nous verrons ce qu'il en dira. Je ne crois pas que les changements que notre goût exige fussent aussi considérables que vous l'imaginez. ${ }^{13}$

Diderot's assessment of the play's acceptability was optimistic. When M. d'Argental proposed its staging at the Comédie Française, it was rejected.

Grimm writing in the Correspondance litteraire in 1768 makes an interesting reference to Diderot's translation methods:

Il y a environ dix ans que cette pièce tomba entre les mains de $M$. Diderot. Frappé 
de quelques traits, il se mit à en croquer une traduction pour la faire connaître à quelques femmes avec lesquelles il se trouvait à la campagne. On imprima presque en même temps une autre traduction, peut-être plus fidèle, parce que $M$. Diderot ne se fait jamais faute d'ajouter ce qui peut se présenter de beau sous sa plume ...14

The other translation mentioned by Grimm was that of the abbé Brute de Loirelle, published in 1762 and, as Grimm suggests, a more exact and faithful rendering of the original. Brute de Loirelle translated both the prologue and epilogue, followed the text closely and rendered in verse the rhyming couplets at the end of each act. Grimm's comments on Diderot's translation are revealing. Donald Schier in an article in Diderot Studies examines its accuracy and concludes that, apart from a couple of gross errors (including the much-quoted confusion between 'wainscot' and 'waistcoat' where, instead of snatching his sword from the wainscot, Beverley takes it from 'une des boutonnières de sa veste'), Diderot's version is not actually unfaithful to the original. However, comments Schier:

Where it fails is in fidelity to the tone of the original. Diderot could not resist the temptation to embellish, develop and refine. ${ }^{15}$

One has only to glance at the two versions side by side on the page to be aware of the extent, in terms of sheer length, of this embellishment.

Diderot's text was the inspiration for Saurin's adaptation of the play, known as Beverley, which appeared in 1768. This work took far greater liberties with the original than did Le Joueur; the prose became blank verse, several characters were eliminated and a small boy, the son of the gamester, was added to the list of characters to increase the pathos of the final act. Here, Saurin's Beverley raises a dagger over the sleeping child and contemplates killing him to preserve him from a life of shame. Saurin also conveniently provided an alternative version with a happy ending in which the news of the inheritance arrives in time to prevent the fatal poisoning. Once again, as in the case of Mercier's Jenneval, stark tragedy is attenuated and transformed to 'drame' in the hands of the French adaptor.

D'Alembert was also attracted by the play, describing it as 'trèsintéressant et très-moral.' He made an adaptation of Beverley's prison monologue which he describes as: 'plein des expressions les plus vives de l'horreur et du désespoir.'16 He expanded the speech and called the piece Le Joueur dans sa Prison: Essai de Monologue Dramatique in which Beverley moralizes at length for the audience's edification. 
Both plays, then, were received with tempered admiration in France. French critics enthused over their poetic imagination and powerful dramatic impact but professed themselves concerned, in varying degrees, at their total disregard for the convention of unity and at the brutal realism of some of their scenes. However, Diderot's approval was virtually unqualified. Concerned with infusing new life into French theatre, he saw them as models for the new 'genre' referred to in his dramatic writings and seemed more than ready to ignore their shortcomings. In an article of the Encyclopédie he enthuses:

Appelez le Marchand de Londres comme il vous plaira pourvu que vous conveniez que cette pièce étincelle de beautés sublimes. ${ }^{17}$

Félix Gaiffe, in his book on eighteenth-century French drama, explains the reason for this strong attraction. Referring specifically to the two tragedies he remarks:

La littérature anglaise offrait aux théoriciens du Drame une réalisation de leur idéal plus audacieuse et plus complète qu'eux-mêmes n'eussent pu la tenter. Il restait à tempérer quelque peu ces hardiesses exotiques pour les rendre acceptables à des spectateurs encore timorés. ${ }^{18}$

As early as 1748 in Les Bijoux Indiscrets, Diderot had satirized the declining state of French classical tragedy where 'l'emphase, l'esprit et le papillotage qui y règnent sont à mille lieus de la nature. ${ }^{19} \mathrm{He}$ continued to react against a genre that he felt had degenerated to little more than a meaningless verbal abstraction, hide-bound by out-dated conventions, to which it was impossible for the new, predominantly bourgeois theatre-going public to relate.

It is not surprising then that, disillusioned with the current state of French tragedy, Diderot should turn to the English theatre in search of models to illustrate his innovative dramatic theories. These two tragedies in the Shakespearean tradition, unhampered by the conventions of unity and 'bienséance' with their sombre and sometimes violent realism were in direct contrast to a French genre that, after Corneille, had become progressively more effete and over-refined. In Diderot's first treatise on dramatic theory, Entretiens sur le Fils Naturel (1757), Dorval and the author discuss the former's conception of a new dramatic genre. Dorval is asked: 'Et ce genre, comment l'appellerez-vous?' and he replies: 'La tragédie domestique et bourgeoise. Les Anglais ont le Marchand de Londres et le Joueur, tragédies en prose. ${ }^{20}$ 
Elsewhere, in a letter to Trudaine de Montigny in 1762, Diderot refers to Landois' Sylvie, written in 1742 , as 'la première tragédie en prose' but allows that although Nous (les Français) avons l'honneur d'avoir fait les premiers pas dans ces genres, il faut convenir que la hardiesse du génie anglais nous a laissés bien en arrière. ${ }^{21}$

Diderot's definition of the new tragedy underlines an attempt to reject the remote realms of kings and princes moved by grand passions in favour of the more intimate crises of a less elevated class. Félix Gaiffe defines it sociologically as:

un genre nouveau créé par le parti philosophe pour attendrir et moraliser la bourgeoisie et le peuple en leur présentant un tableau touchant de leurs propres aventures et de leur propre milieu. ${ }^{22}$

In the third Entretien, Dorval, the mouthpiece for Diderot's theories, elaborates his formula for 'la tragédie domestique':

un renversement de fortune, la crainte de l'ignominie, les suites de la misère, une passion qui conduit l'homme à sa ruine, de sa ruine au désespoir, du désespoir à une mort violente, ne sont pas des événements rares. ${ }^{23}$

According to Diderot, such events would be no less moving than la mort fabuleuse d'un tyran, ou le sacrifice d'un enfant aux autels des dieux $\mathrm{d}^{\prime}$ Athènes ou de Rome'24.

Both The London Merchant and The Gamester clearly fit the formula. George Barnwell's downfall is brought about by his passion for Millwood, Beverley's by his passion for gaming. Both die violently, Barnwell on the gallows, Beverley by poisoning himself in his prison cell.

The bourgeois milieu was sufficiently innovative in English tragedy in 1731 to warrant its defense by Lillo in the Dedication of the play:

If princes, etc. were alone liable to misfortunes arising from vice or weakness in themselves or others, there would be good reason for confining the characters in tragedy to those of superior rank; but, since the contrary is evident, nothing can be more reasonable than to proportion the remedy to the disease. ${ }^{25}$

He describes his play in the Prologue as 'a tale of private woe,' a definition that could equally be applied to the Gamester where the setting is one of bourgeois domesticity in which the audience witnesses the gradual disintegration of hearth and home brought on by the excesses of Beverley's passion for gambling. It should be noted that, although the setting for Lillo's play is Elizabethan, the tone is clearly of the eighteenth 
century with the sentimental emphasis on family virtue and professional morality and the exaltation of the beneficial effects of commerce. Thorowgood, loving father and honest merchant, is the prototype for a number of characters appearing in later examples of the 'drame bourgeois' notably in Sedaine, Beaumarchais and Mercier, and exemplifies the type of character promoted by Diderot in what he calls 'la peinture des conditions.'

The desire for realism led inevitably to a discussion of the relative merits of verse and prose. Diderot examines the question in both the Entretiens and the Discours de la Poésie dramatique. If the new genre was to be a realistic representation of everyday happenings, it followed that the language could only logically be that of prose. The two English plays are acclaimed by Dorval in the second Entretien as 'tragédies en prose' and this in contrast to the language of current French tragedy where, according to Dorval:

Nous [les Français] avons conservé des Anciens l'emphase de la versification qui convenait tant à des langues à quantité forte et à accent marqué ... et nous avons abandonné la simplicité de l'intrigue et du dialogue. ${ }^{26}$

In the third Entretien, whilst allowing that 'la tragédie ancienne' should use measure, Dorval states that la tragédie domestique me semble exclure la versification. ${ }^{27}$ In the Discours, Diderot's comments are more vague:

Je me suis demandé quelquefois si la tragédie domestique se pouvait écrire en vers; et, sans trop savoir pourquoi, je me suis répondu que non..$^{28}$

The use of prose in tragedy in the English theatre of the period was unusual enough to warrant a defense by Moore in the preface to his play. $\mathrm{He}$ argues in its favour on the grounds that he hopes to be 'more interesting, by being more natural. ${ }^{29}$ However he goes on to explain that the level of the language will vary according to the character; for the 'lower characters' blank verse would be 'unnatural if not ridiculous' but, according to Moore, 'though the more elevated characters also speak prose, the judicious reader will observe, that it is a species of prose which differs very little from verse; and in many of the more animated scenes, I can truly say, that I often found it a much greater difficulty to avoid, than to write, measure. ${ }^{\prime 30}$

If Moore admits this problem, Lillo reveals an even stronger tendency to lapse into blank verse. As Lawrence Price demonstrates, Barnwell's soliloquy during the murder scene is difficult to read as anything other 
than verse and many of the more commonplace passages have an equally and unnaturally elevated style. ${ }^{31}$

Nevertheless, the use of prose was a major breakthrough and one of which Diderot approved. Both English dramatists retained the convention of rhyming couplets, Moore at the end of each act, Lillo more frequently to point a particular moral. However, in his translation of Moore's play, Diderot, true to his theory, insists on rendering the couplets in prose, linking them to the final speech of the act.

Again in the interests of realism, Diderot reacts against the outmoded and excessive strictures inherent in the convention of 'bienséance' which, more than the constraints of the unities, were responsible for the decline of French classical tragedy to something approaching a verbal abstraction. 'La bienséance' embraced anything from immorality on stage to what might be considered the slightest breach of good taste. This had the effect of reducing physical action to a minimum, the technique of the 'récit' being used to relate violent or tragic happenings. Suicide alone was permitted if discreetly executed. Little attention was paid to scenic details or stage directions. It is well known that much of Diderot's dramatic theory, particularly in Le Paradoxe sur le Comédien, stresses the role of the actor with emphasis on the use of gesture, pause, pantomime and what he describes as 'tableaux vivants' in the manner of a Greuze painting. The exaggerated emphasis on detailed scenic directions in his own plays points to his determination to convert these theories into practice.

In the introduction to the Entretiens, Diderot asserts that 'une pièce est moins faite pour être lue que pour être représentée. ${ }^{\prime 32}$ Furthermore, he advocates the direct representation of the pathetic and the violent, arguing that if such scenes can appear realistically in painting, there is no reason for them to be proscribed on the stage. In the first Entretien, Dorval asserts:

Je pense, pour moi, que si un ouvrage dramatique était bien fait et bien représenté, la scène offrirait au spectateur autant de tableaux réels qu'il y aurait dans l'action de moments favorables au peintre. ${ }^{33}$

The 'Moi' of the Entretiens protests in response: 'Mais la décence! la décence!' and it is at this point that Dorval refers to a scene from Lillo's play, equating it in terms of pathetic impact with that of Sophocles' Philoctetes writing outside his cave:

Je n'entends répeter que ce mot. La maîtresse de Barnvelt entre échevelée dans la prison de son amant. Les deux amis s'embrassent et tombent à terre. ${ }^{34}$ 
The fact that Diderot is confused by the circumstances of the action (it is, in fact, Trueman, Barnwell's friend, who lies with him on the prison floor), does not detract from the impression that the pathos of the scene made on him. He refers to it again in the Discours de la Poésie dramatique where he actually quotes the friends' farewell exchange in which Barnwell admits that the extent of his passion for Millwood would have led him to murder Trueman, had she told him to do so. Diderot is overwhelmed by the nobility of Trueman's response:

"Nous ne nous sommes pas encore embrassés": quelle réponse à "je t'aurais assassiné!" Si j'avais un fils qui ne sentît point ici de liaison, j'aimerais mieux qu'il ne fût pas né. ${ }^{35}$

In the second Entretien, in the speech in which he has made reference to the two English tragedies, Dorval reiterates his plea for realism. He speaks of the new genre as presenting on stage 'des situations naturelles qu'une décence ennemie du génie et des grands effets a proscrites. ${ }^{\prime 36}$ Diderot is more audacious in theory than in practice. Although he admires the boldness of the English tragedies, his own plays in no way reflect their sombre realism.

But, for Diderot, realism is not an end in itself. As Michel Lioure remarks of the new genre:

Loin d'être une fin en soi, le réalisme dramatique n'est donc qu'un instrument au service du pathétique et du didactisme. ${ }^{37}$

If the object of a dramatic work, according to the third Entretien, is 'd'inspirer aux hommes l'amour de la vertu, l'horreur du vice, ${ }^{\prime 38}$ then the violence of the emotion evoked in the spectator will be justified in terms of the effectiveness of the moral lesson. When 'Moi' asks Dorval in the third Entretien if there should be restrictions on what is represented on stage, suggesting that 'on veut être attendri, touché, effrayé; mais jusqu'à un certain point,' Dorval's response is unequivocal:

Ainsi, dire qu'il ne faut les [les hommes] émouvoir que jusqu'à un certain point, c'est prétendre qu'il ne faut pas qu'ils sortent d'un spectacle, trop épris de la vertu, trop éloignés du vice. Il n'y aurait point de poétique pour un peuple qui serait aussi pusillanime. ${ }^{39}$

Both Lillo and Moore echo these sentiments. Moore, in the Preface to The Gamester, argues in defence of 'the horror of its catastrophe': 
I should humbly presume that the working it up to any uncommon degree of horror, is the merit of the play, and not its reproach. Nor should so prevailing and destructive a vice as gaming be attacked upon the theatre, without impressing upon the imagination all the horrors that may attend it. ${ }^{40}$

Lillo, in the Dedication of his play, sees the end of tragedy as being the exciting of the passions in order to the correcting such of them as are criminal, either in their nature or through their excess. ${ }^{41}$

Both tragedies, with the exaggerated pathos of their prison scenes, their emphasis on death as punishment for evil and their constant moralising, have led them to be described as 'dramatised sermons.' They could hardly fail to appeal to a writer whose theatrical output has been characterised by Roger Lewinter as 'une prédication laïque. ${ }^{42}$

However, although both Diderot and the two English playwrights exalt virtue, the moral is not the same. Lillo and Moore, both Dissenters, preach a tough Christian ethic stressing the sinfulness of man, punishment for evil, repentance and redemption. Lillo lays great emphasis on Barnwell's penitence in the final prison scenes and his death is contrasted with that of Millwood who dies defiant and unrepentant. For both Barnwell and Beverley, restored virtue will only be rewarded in heaven after the punishment of death. For Diderot and the 'parti philosophe,' the emphasis is on the essential goodness of man, and the reward for 'la vertu,' described by Lewinter as the 'divinité profane d'une sociéte sceptique ... le Dieu athée de la société bourgeoise, ${ }^{\prime}{ }^{43}$ is an earthly one. Hence the tendency for French dramatists of the period to write 'drame' with its invariably happy conclusion rather than tragedy. (Diderot himself planned but never wrote, a tragedy entitled Le Sherif.)

Despite this ethical divergence, the strong didactic nature of the plays was undoubtedly one of the elements that particularly appealed to Diderot and one which he emulated in his own writings for the theatre. The language of prose and the bourgeois setting were also faithfully adhered to by the author of Le Fils Naturel and Le Père de Famille and yet Diderot's plays with their self-conscious verbiage, excessive sentimentality and happy outcome bear little ressemblance in tone to the sombre, sometimes crudely violent and pessimistic atmosphere of The London Merchant and The Gamester.

Audacious in their realism, unfettered by rigid dramatic conventions, the tragedies of Lillo and Moore responded to an ideal for which Diderot and his followers were unable to find satisfactory models in the theatre of their own nation. Translated, modified and adapted to meet the stringent requirements of the French stage, cited as exemplifying a new dramatic 'genre,' The London Merchant and The Gamester played their role, 
together with other English influences, in the gradual evolution of theatre and dramatic theory in eighteenth-century France.

\section{F.M. WILKSHIRE}

Memorial University of Newfoundland

\section{Notes}

1 Le Pour et Contre, III (1734) 337-56

2 Ibid., 350

3 Ibid., 344

4 Le Marchand de Londres ou l'Histoire de George Barnwell, traduite de l'Anglois de M. Lillo par Pierre Clément (1748) Act V, sc. ix

5 Ibid., Act V, sc. ix

6 Ibid., Act I, sc. v

7 Price, Lawrence M., 'George Barnwell Abroad' Comparative Literature 2 (1950) 126-56

8 Collection complète des Oeuvres de Claude Dorat (Neuchatel, 1776), I, 1-4

9 Correspondance littéraire, $1^{\mathrm{er}}$ avril, 1764, ed. Tourneux (Paris: Garnier 1878), V, 475-9

10 Théatre complet de M. Mercier (Amsterdam, 1788), I, 5

11 T. Vincent Benn, Notes sur la fortune du George Barnwell de Lillo en France,' Revue de Littérature comparée 6 (1926) 687

12 Diderot, Oeuvres Complètes, ed. Le Club Français du Livre, IV, 15-281

13 Quoted by J. Assézat, Notice préliminaire du Joueur, Oeuvres Complètes, VII, 413

14 Correspondance littéraire, ed. Tourneux. (Paris: Garnier, 1878), VIII, 75

15 D. Schier, 'Diderot's Translation of the Gamester,' in Diderot Studies 16 (1973) 240

16 D'Alembert, Oeuvres Complètes, ed. Slatkine Reprints, (Genève 1967), IV, 475

17 Quoted by J. Texte, J-J. Rousseau et les Origines du Cosmopolitisme littéraire (Paris, 1895), 169

18 Félix Gaiffe, Le Drame en France au XVIII ${ }^{e}$ Siècle (Paris: Armand Colin 1970), 56

19 Diderot, Oeuvres Romanesques, ed. Bénac (Paris: Garnier 1967) 
20 Diderot, Oeuvres Esthétiques, ed. Paul Vernière (Paris: Garnier 1968), 119-20

21 Oeuvres Complètes, ed. Le Club Français du Livre, V 155.

22 Gaiffe, 78

23 Diderot, Oeuvres Esthétiques 149

24 Ibid.

25 George Lillo, The London Merchant, ed. W. McBurney, Regent's Restoration Drama Series (1965), 3

26 Diderot Oeuvres Esthétiques, 121

27 Ibid., 167

28 Ibid., 216

29 Edward Moore, The Gamester, The Augustan Reprint Society (1948), 417.

30 Ibid., 417-18.

31 Price, 130

32 Diderot, Oeuvres Esthétiques 78

33 Ibid., 90

34 Ibid., 90

35 Ibid., 255

36 Ibid., 120

37 M. Lioure, Le Drame de Diderot à Ionesco (Paris: Colin 1973), 35

38 Diderot, Oeuvres Esthétiques, 152

39 Ibid.

40 Moore, 418

41 Lillo, 3

42 R. Lewinter, 'L'Exaltation de la vertu dans le théâtre de Diderot,' Diderot Studies 8 (1965) 128

43 Ibid., 128 